\title{
Problems and Countermeasures in Graduation Design of Information Management and Information System Specialty
}

\author{
Shuang Gao, a ${ }^{1,}$ Jingshu Wang ${ }^{1, b}$ and Chuanlin Huang ${ }^{1, c}$ \\ ${ }^{1}$ No. 8, software park road, Dalian, Liaoning, China \\ agaoshuang@neusoft.edu.cn, bwangjingshu@neusoft.edu.cn, chuangchuanlin@neusoft.edu.cn
}

Keywords: Graduation design; Information management and information system specialty; Countermeasure

\begin{abstract}
Graduation design work is great significance to train students' practical ability, innovative ability and entrepreneurial ability, and improve the quality of teaching in an all-round way. Analysising of several aspects of the graduation design of information management and information system specialty, combined with many years of experience in graduation design guidance, to put forward countermeasures to improve graduation design quality.
\end{abstract}

\section{Introduction}

Graduation design is a very important link in the teaching of higher education, which is an examination of students' comprehensive quality and ability. Graduation design can comprehensively show students mastery of knowledge and ability to use knowledge, can train students to seek truth from facts, analyze and solve problems, hands-on practice and innovation and entrepreneurship and other abilities. The quality of graduation design is an important indicator to test the university talent training objectives can reach.

The information management and information system Specialty is a comprehensive and interdisciplinary subject. Its discipline foundation is composed of three parts: modern management science, modern information science and information technology, modern system science and system engineering [1]. It train practical talents for master of economics, management theory and methods, familiar with computer science knowledge and application technology, possess information management knowledge and skills, possess information systems analysis and design capabilities, in various national management departments, business, education, Scientific research, finance, library and information and other units to undertake information management, in a variety of information systems construction, planning and management of integrated.

\section{Research Status}

For the status quo of the research on the quality of graduation project of information management and information system Specialty, Zou Biyu et al. [2] analyzed the common problems in the subject, content, grade evaluation and quality of the graduation project of Information Management and Information System, discussed the specific methods and corresponding measures of graduation design quality management and control from the early stage, middle stage and later stage of graduation design. Wang Xiao et al. [3] analyzed the problems existing in graduation design of information management and information system specialty, Put forward the construction of graduation project quality monitoring system; Xu Chaoyi et al [4] discussed the problems existing in graduation design of information management and information system Specialty of Anhui University of Science and Technology, and put forward ways to improve graduation design quality through thinking and innovation. 


\section{The Problems in the Graduation Design of Information Management and Information System Specialty}

The Problems of Teachers as Lack of Experience, Limited Knowledge Areas and So On. One of the important factors that affect the quality of graduation design is the lack of guidance from teachers. In recent years, the enrollment of colleges and universities has been constantly expanding, and the allocation of teacher resources can not keep up with the growth of the number of students. As a result, some school teachers are over-guided in their graduation projects and their tasks are too heavy to guarantee the quality of guidance. In order to meet the demand of teacher resources, many colleges and universities are also actively recruiting talented people. However, most young teachers who just graduated from school lack the scientific and correct methods and experiences of graduation design to a certain extent, reduce the quality of graduation design in a certain extent.

There are four major types of information management and information system courses: economic management, engineering mathematics, computer science and information system [5]. Therefore, the professional development of the information management and information system profession is a composite talent with more comprehensive and comprehensive information system knowledge, Information management and information systems professional graduation project can not only involve a simple management class or information technology knowledge, but the information technology and management theory to consider and solve the problem. Some professional teachers, due to their strong professional skills, are not deep in some fields and difficult to guide students' dissertations. In addition, because some old teachers have less contact with new knowledge, new ideas and new technologies, it is difficult to give students some innovative guidance. There are also some teachers who lack scientific research and engineering practice and social practice background, which will also reduce the quality of graduation design guidance.

Students don't Pay Enough Attention to Graduation Design. Graduation design is usually arranged in the next semester of senior year, which is the important period for students to face employment, find a job and prepare for the postgraduate examination. In addition, students do not know enough about the overall work of graduation design, and their concept of time is not strong. Cause to treat graduation design attitude not serious, deal with perfunctory. For example, some students did not really understand the main research content of the topic at the beginning of the topic selection, but blindly chose the topic according to their own preference. It has negative influence on the development of post-graduation design work.

Lack of Scientific Process Management Methods and Regulatory System. Graduation design is an important basis to measure the teaching level as well as students' graduation and degree qualification. However, due to the long graduation design cycle and the many tasks, the management center lacks effective monitoring of the graduation project design and the effective supervision mechanism and reward and punishment measures for the graduating teachers, resulting in graduation design process Management is relatively loose, the relevant system is not implemented in a timely manner, not strict; some teachers graduation design enthusiasm is not high, did not take seriously, the work schedule is not timely; students pay insufficient attention to the graduation design; graduation design of some managers Quality problems to accommodate, tolerant attitude, graduation design answer to mere formality. All of the above have seriously affected the quality of graduation design.

\section{Information Management and Information System Graduation Project Design Quality Improvement Measures}

Strengthen the Construction of Teaching Staff. Teachers play a very important leading role in graduation design. Schools should be equipped with sufficient teachers according to the number of professional students, should pay attention to the introduction of talented people, improve the teaching staff, appropriate to reduce the pressure of teachers; to guide a reasonable amount of the graduation project design workload, improve teachers' enthusiasm. 
Some of the young mentors should be carried out relevant training to improve their own quality and ability, and to clarify the content of graduation design. Young mentoring teachers and old teachers can pair with each other. Young teachers can learn the graduation design methods and precious experiences from the old teachers. Young teachers can also provide some new ideas to the old teachers and introduce new technologies and tools. Both sides complement each other to improve the quality of graduation design guidance.

In addition, project engineers and enterprise tutors who are actively introduced into the enterprise can be jointly guided by the way of cooperation between schools and enterprises so as to help absorb the more advanced ideas and technologies in the industry and enhance their practical value.

To Enhance Students' Awareness of the Importance of Graduation Design, Strengthen the Guidance and Direction to Students. A high quality undergraduate thesis requires a long-term accumulation process. From the beginning of students touch with specialized courses, teachers should appropriately emphasize the relevant contents of professional graduation design, enhance students' understanding of graduation design earlier, and remind students to pay more attention The accumulation of professional knowledge. Before students start graduation design, carrying out the graduation design propaganda by profession units to popularize the goal and importance of graduation project, to convey the whole process of graduation project design and direction of the topic.

Teachers and quality teachers should work together to guide students to arrange internships, postgraduate entrance examination, job search and graduation design of these aspects. At the beginning of graduation design, the teachers should explain to the students the overall work of the graduation project design, guide the students to formulate the graduation project work plan scientifically, and promptly supervise and check the completion of the tasks of the students.

According to the actual situation of students, teachers can conduct the graduation design guidance and the work of answering questions through online or offline mode. At the same time, also can appropriate be attention to student's life, study and work progress, through a better understanding and grasp of the current situation of students, strengthen the contact between teachers and students, to give students more effective guidance.

To Strengthen the Process of Graduation Design Management from Top to Bottom, and Implement the Whole-Process Quality Monitoring. At the school level, a scientific and rigorous system of graduation design rules shall be promulgated, regulations on graduation design work should be clearly defined, such as specifications for writing, methods for determination and treatment of fraud, mid-term examination programs, management regulations for off-campus internship, management of graduation design funds, methods for selecting papers and archives Standardization requirements. Each faculty should formulate a specific graduation design and implementation standard according to the graduation design rules of the university and the characteristics of their respective disciplines to clear graduation design teaching objectives, teaching requirements, teaching arrangements, archiving requirements, as well as grading standards.

In strict accordance with the above specifications and strengthen the whole process of quality control. All faculties should set up a special supervision team for graduation design work, formulate timely and effective quality inspection mechanisms, strengthen the supervision of instructors, and examine all aspects of the graduation project, including the selection of topics, opening questions, mid-term examinations, pleadings, performance appraisals and Archiving and other stages.

Fair and reasonable treatment results can be linked to faculty, professional and teacher performance appraisal, or certain rewards and punishment measures should be introduced to strengthen the management effect of graduation design process and improve the quality of graduation design.

To manage the whole process of graduation design by means of informatization. Graduate design involves many links, long cycle, management is difficult, so we can through the network of graduation design management system to improve graduation design management [6]. From the declaration and review of the design topics and the mission statement to the two-way selection of students and teachers, the submission and review of achievements in the middle and later stages of the pre-graduation project, the record of the students during the graduation project, and the guidance record 
of the teachers, system management can be used together to facilitate the instructors to keep abreast of the students' graduation design work and to simplify the related information management work. This not only ensures the consistency and accuracy of information but also supervises the whole process of graduation design.

\section{Conclusion}

As an important part of college teaching plan, graduation design is a comprehensive assessment of students' knowledge, qualities and abilities. It is of great significance to train the practical and innovative entrepreneurial ability of information management of students by strengthening the graduation project management and improving the quality of graduation project. In college education, we should constantly analyze and reserch the problems in the process of graduation design, and use creative thinking to solve the problems in graduation design so as to continuously improve the quality of graduation design and train more talents with high quality and high ability professional.

\section{References}

[1] P.P.Zhang. ERP in the graduation design of information management and information system specialty [J]. Inner Mongolia Science and Technology and Economy, Vol. (2014)No.6,P.53.

[2] B.Y.Zou, J.Tian. Management and Control of Graduation Project of Information Management and Informa(in chinese)tion System [J]. China Forest Education, Vol.25 (2007)No.3,P.18

[3] X.Wang, Y.Jiang. Construction of Quality Supervision and Management System of Graduation Project of Information Management and Information System [J]. Science and Technology Information, Vol. (2013)No.24,P. 13

[4] C.Y.Xu, R.Hu. Thinking and innovation of Information Management and Information System professional graduation design [J]. Higher Education Forum, Vol. (2008)No.5,P.162

[5] R.WANG,Y.F. SUN. Exploring the Graduation Design of Information Management and Information System [J]. Computer Knowledge and Technology, Vol.5 (2009)No.22,P. 6095

[6] F.H.Liu, L.H.Yuan. Construction of Graduation Design Network Management Information System [J]. Digital Communications World, Vol. (2017)No.10,P.152 